\title{
How integrating 'socio-cultural values' into ecosystem services evaluations can give meaning to value indicators
}

\author{
Johanna Breyne $^{\mathrm{a}, *}$, Marc Dufrêne ${ }^{\mathrm{a}}$, Kevin Maréchal ${ }^{\mathrm{b}}$ \\ ${ }^{a}$ University of Liège, Gembloux Agro-Bio Tech, Terra, Biodiversity and Landscape, Passage des Déportés, 2, Gembloux 5030, Belgium \\ ${ }^{\mathrm{b}}$ University of Liège, Gembloux Agro-Bio Tech, Terra, Economics and Rural Development, Passage des Déportés, 2, Gembloux 5030, Belgium
}

\section{A R T I C L E I N F O}

\section{Keywords:}

Ecosystem services

Socio-cultural values

Stakeholders' perceptions

Forest management

Value pluralism

Subjective indicators

\begin{abstract}
A B S T R A C T
As an attempt to clarify the meaning of 'values' within ecosystem services (ES) assessments, this paper proposes the integration and fine-tuning of the concept of 'socio-cultural values' within the ES assessment framework. Firstly, it makes a conceptual clarification between biophysical, social or monetary value indicators describing the performance of a service, and socio-cultural values reflecting opinions on the importance of a (set of) service (s). Secondly, it provides a practical application to illustrate how to interpret 'social value indicators' through their interactions with 'socio-cultural values'. An adequate use of these 'socio-cultural values' combined with subjective social value indicators' makes it possible to take the opinion of a wide range of actors into account and to give meaning to their expressed preferences instead of blindfolding on caricaturized profiles. The case study in this paper deals with the Ardennes forests (Belgium). Wider public preferences for different structural forest characteristics (as performance-oriented ES value indicators) actually relate to different 'socio-cultural values'. The study results reveal a mismatch between current forest management strategies and wider public preferences. This paper clearly demonstrates the potential of 'socio-cultural values' to improve legitimacy and to foster consensus-building of decision-making in natural resource management.
\end{abstract}

\section{Introduction}

Despite the popularity of the Ecosystem Services (ES) approach to guide the study and operationalization of human-nature dependencies (Costanza et al., 2017), it has been criticized for its strong normative framing (Robertson, 2006). The term "normative" refers to the ES conceptual framework assuming that nature is a service provider, whereas this is only one way of seeing nature. Moreover, which services are then being provided strongly depends on who is judging. In reply, ES have been redefined as 'the benefits that humans recognize as obtained from ecosystems that support, directly or indirectly, their survival and quality of life' (Harrington et al., 2010). The addition of the verb 'to recognize' does indeed make the anthropocentric framing of the ES concept more evident since it underlines the point that ES need to be identified by humans in order to exist (Barnaud et al., 2018). It is this definition of ES that has been adopted in this paper. Moreover, since different people recognize different services, this definition also highlights the importance of accounting for diverse sets of values and evaluations when applying the concept to policy and decision-making (Barnaud et al., 2011; Davies et al., 2015; Hauck et al., 2013; Jacobs et al., 2016; Jax et al., 2013; Martín-López et al., 2014).

Values should be understood as an umbrella concept covering a broad range of different interpretations of what the word 'value' stands for (Spangenberg and Settele, 2016). There are thus various ways to define, classify, assess and express them. However, the way values are conceptualized and measured is subject to ambiguity (Anderson et al., 2018; Kenter et al., 2019) in the sense that certain sets of values are either easily ignored, downplayed or conflated.

First, the issue of certain sets of values being ignored has triggered a call for an integration of multiple sets of values into ecosystem service assessments (Boeraeve et al., 2015; Jacobs et al., 2016; Kenter et al., 2016; Martín-López et al., 2014). The recent revision of some main ES frameworks has indeed included multiple values in the amended versions (CICES, 2018; Díaz et al., 2015; Fish et al., 2016; Pascual et al., 2017). Second, a socio-cultural interpretation of values is often downplayed to the benefit of economic interpretations in ES evaluations and applications (Byg et al., 2017; Chan et al., 2012; Pröpper and Haupts, 2014; Scholte et al., 2015). Thus, even when multiple value sets are assessed, the question of how to integrate, combine or use them for decision-making processes remains a challenge (Dendoncker et al.,

\footnotetext{
* Corresponding author.

E-mail addresses: johanna.breyne@uliege.be (J. Breyne), marc.dufrene@uliege.be (M. Dufrêne), K.Marechal@uliege.be (K. Maréchal).
} 
2018; Kronenberg and Andersson, 2019). Third, and related to the previous point, is the tendency to conflate the performance of a service with its importance. With performance we refer to the assessed state or trend of (an) ES; with importance we refer to what extent and how this service or its associated benefits matter (in non-monetary terms) for someone or for a group of persons. This is a fundamental aspect since not assessing the various opinions on importance can cause to overlook crucial interdependencies between services, benefits and concerned actors and thus hamper an inclusive valuation. For example, the performance of timber provisioning (i.e. an ES under consideration when assessing forest ecosystems) could be assessed by biophysical indicators (e.g. the total area under forestry or the volume of annual round wood removals), by economic indicators (e.g. the market price per $\mathrm{m}^{3}$ ) as well as by social indicators (addressing non-monetary social aspects of the ES). These latter could either be objective (e.g. the number of employments in the timber value chain) or subjective (e.g. the preference for a certain wood type). However, these valuation outcomes do not address the multitude of meanings or ways in which the ecosystem matters for different groups or persons. These latter notions of importance and meaning-making are strongly shaped by the socio-cultural context of the concerned actors (Berbés-Blázquez et al., 2016; Brondízio et al., 2010; Tadaki et al., 2017).

Bearing these considerations in mind, this paper operationalizes a socio-cultural valuation approach for the assessment of ecosystem services. This means that services and their related benefits are valued in a contextualized way, acknowledging that values are shaped by the broader social context, worldviews and social perceptions (Díaz et al., 2014). Within this paper it does so through assessing both indicators of ES performance and indicators of ES importance. By means of an empirical case study, it explicitly addresses the relationship between both aspects through linking preferences for management options, as indicators of performance, with expressed opinions on the importance of various services or benefits provided by the same ecosystem. Our aim is to assess how this socio-cultural approach can provide relevant insights for the management of natural resources by explicitly integrating opinions on importance into ecosystem services assessments.

\section{Theoretical background}

\subsection{The relationship between ES performance and importance}

Substantial work has been undertaken to address the different ways of approaching values in environmental valuations (e.g. Arias-Arévalo et al., 2017; Cáceres et al., 2015; Chan et al., 2012; Christie et al., 2019; Gould et al., 2019; Ishihara, 2018; Kendal and Raymond, 2019; Kronenberg and Andersson, 2019; Maynard et al., 2015; O'Connor and Kenter, 2019; Peltola and Arpin, 2017; Rawluk et al., 2019; Stålhammar and Thorén, 2019; Van Riper and Kyle, 2014; Irvine et al., 2016). According to, Kenter et al., 2015, 2019), three main concepts of values can be identified: (1) transcendental values as broader core values covering ethic principles or desired end states; (2) contextual values that address the worth or importance of something; and (3) quantitative or qualitative value indicators as outputs of some form of evaluation. Broad transcendental values are said to influence the more tangible contextual values, which, in turn, influence the choice for concrete value indicators (Kronenberg and Andersson, 2019). For values to be explicitly considered in a decision-making processes, they need to be visualized or translated into commonly understood units and communicated. For instance, the category of performance indicators can be expressed through amounts of money, maps and indices (Kenter et al., 2016), while the expression of the meaning and importance of a service (including its emotional, affective and symbolic aspects) can for example take place through rankings or testimonials.

Within an ES assessment framework, values fulfill a mediation function between benefits and processes of governance, which, in turn, can give rise to concrete actions regarding the management of natural resources and ecosystems (Daily et al., 2009; Díaz et al., 2015; HainesYoung and Potschin, 2010). It has been pointed out that broader categories of values, such as transcendental or contextual values, are limited in their expression in terms of actions, which render them less applicable for applied research (Kollmuss and Agyeman, 2002). It should be underlined, however, that the use of performance indicators at best only partially reveal underlying aspects of importance. A focus on mere performance indicators could therefore aggravate mismatches between environmental management and societal expectations and, in turn, lead to social tensions and conflict (Anderson et al., 2018). Explicitly assessing both indicators of ES performance and indicators of opinions on the importance of those ES and linking these directly or indirectly to one another, allows for partially addressing this issue.

To this respect, Aretano et al. (2013) call for both using objective and subjective indicators to perform ES evaluations. Subjective indicators are understood as self-reported (individually or collectively) preferences (Bryce et al., 2016; Harrington et al., 2010). While preferences in themselves do not necessarily reflect a notion of importance or meaning, they can more easily be linked to expressed opinions of importance than other performance-oriented indicators. In that respect, preferences appear well-suited to bridge the gap between objective measures of performance and the meaning attached to the measured elements, thereby facilitating an integrated ES evaluation.

For example, residents close to a forest could strongly dislike the presence of deadwood within it, but at the same time find the biodiversity aspect of the forest very important. This could indicate discrepancies between preferences and the ecological status of the same natural resource (Scholte et al., 2015) and provide an incentive for the government to make efforts towards awareness-raising regarding the positive effects of deadwood on biodiversity. While preferences for a specific aspect (e.g. the presence of deadwood) might be diverging, overarching meanings (e.g. biodiversity conservation) might be shared, thus generating a common basis for discussion or communication. Conversely, preferences for that specific aspect might be similar, while underlying meanings might be different or differently prioritized (e.g. biodiversity conservation and aesthetic appreciation) and thus be differently affected when landscape elements change (e.g. when a bark beetle outbreak causes large die-offs). Hence, while broader categories of values are less easily applicable to nature management, it is possible to address them by gaining insights into their relationships with the category of performance indicators. It is important to note, however, that the choice for certain indicators (whether they are objective or subjective) is also framed by the socio-cultural context and thus not a neutral element. This should be acknowledged and explicitly taken into account (Breslow et al., 2017; Martín-López et al., 2014).

\subsection{What are socio-cultural values for ES?}

Within the ES framework, values and valuation methods have been commonly divided into three domains/dimensions (with terminology depending on the author), which are: ecological/biophysical, social/ socio-cultural and economic/monetary (Kronenberg and Andersson, 2019; Martín-López et al., 2014; Stålhammar and Thorén, 2019). This categorization, however, does not leave any room for introducing the notion of importance in a way that does not cause conflation.

Therefore, we consider these three domains as referring to the ES value indicators used to describe the performance of a service, which is to be distinguished from opinions on the importance of that same service. In a socio-cultural valuation approach, valuation is thus performed on two levels: (i) the evaluation of the performance of a service through objective and subjective non-monetary indicators, to which we refer to as 'social value indicators' and (ii) the evaluation of opinions on the nonmonetary importance of a service or benefit within a given context through 'socio-cultural value indicators'. As Kenter et al. (2015) pointed out, the term "social values" can refer to different usages. The word "social" can be used to indicate a societal or shared interpretation of the 
aspect at stake, as in social process, social problem, social scale, etc. Shared values, which are to be distinguished from individual values since they refer to values expressed by a set of people who belong to a same group (Kenter, 2019), also belong to this type of use. In addition, the term social can also be used to refer to one of the three abovementioned value domains, next to the ecological and economic value domains. This latter use has often been linked to the original category of cultural ES, thereby representing non-monetary values to describe cultural services (Sherrouse et al., 2011). Social value indicators thus do not measure a specific socio-cultural value. They instead measure an aspect of the performance of a certain service for/to which a person holds/assigns a certain importance, the latter being what we call a socio-cultural value. Since the objective and/or subjective social values indicators that will be used to asses a given ES performance ultimately depend upon the socio-cultural (including institutional) context within which the valuation takes place, we acknowledge that social value indicators are not completely independent from socio-cultural values. However, since social value indicators do not necessarily entail notions of importance, we propose to explicitly look at the interaction of performance and importance through assessing the interactions between social value indicators and socio-cultural value indicators.

As a matter of illustration, let us consider, for instance, the case of landscape attractiveness for tourism activities as an ES. Its performance could be described by a set of biophysical value indicators (e.g., hectares of accessible forest), economic value indicators (e.g., the willingness to pay to visit certain landscapes) and social value indicators (e.g., tourist preferences for certain landscape characteristics). Socio-cultural (SC) values, in turn, could point out the importance of therapeutic, patrimonial, economic and other values related to a variety of services provided by that same landscape. It must be noted that socio-cultural values may encompass negative repercussions (e.g., a negative feeling related to mass tourism). SC values represent a process of giving meaning/ assigning importance to ES by different actors (Munda, 2004). An ES demand may thus entail a concrete demand for the service in se (e.g., grasped by a performance indicator such as the number of accessible hectares) in order to modify the indicator outcome in future evaluations (e.g., to increase the number of hectares), or result from a will to give more weight to a service (e.g., perceived through SC values that reflect the importance of forests as a leisure area).

In this paper, the term 'social value indicators' is used to qualify those indicators belonging to the social value domain. The term sociocultural values is of a distinct nature and is used to denote 'an opinion on the non-monetary importance people, as individuals or as a group, assign to (bundles of) ES (based on Scholte et al., 2015). SC values can thus be either individual or shared values and may or may not concern a service with a social intention. Within this definition, the term "cultural" thus adds a process of meaning-making (Fish et al., 2016; Pröpper and Haupts, 2014). As far as debate on environmental values and their categorization within the ES assessment framework is concerned, SC values can be deemed as touching upon instrumental, intrinsic, as well as relational values (Arias-Arévalo et al., 2017; Small et al., 2017). Whether values exist as inherent to nature, or whether valuation is, by definition, an outcome of human activity, is a matter of debate. However, human valuation is surely not limited to instrumental values only (Jax et al., 2013). Socio-cultural values provide a space to express relational values as well, and, to some extent, intrinsic values since-although by definition these are not considered within the ES concept-intrinsic values are inevitably intertwined with people's interpretations of ES (Chan et al., 2012; O'Connor and Kenter, 2019). SC values echo the aforementioned broader literature on values in which we situate SC values as being contextual and place-based (Tadaki et al., 2017). However, while SC values are framed as place-based since they address the importance of services and benefits within a same ecosystem, this does not necessarily mean that the specific SC value is expressed as place-based. For instance, while patrimonial values are likely to be interpreted as place-based, biodiversity values are likely to represent an overall concern.

As an illustration, let us consider the ecosystem service of a natural area as a place where people can experience nature, such as the Abruzzo National Park in Italy. To evaluate this service and how it performs, a value indicator is decided on, measured and represented by a specific unit. In this case, a biophysical value indicator could be the number of brown bears (Ursus arctos marsicanus), the emblematic species of the Abruzzo National Park; an objective social indicator could be the number of local institutions that use the image of the bear in their communication; and an economic indicator could be the cost associated to the distance people are willing to travel to observe this species. Once an evaluation methodology is agreed upon, the factual outcome (e.g., the bear population size) is a given. However, what this number means depends on who is interpreting it and in which context. It can thus be subject to discussion. For example, a high number of bears could be interpreted as positive by tourists wanting to observe this species, but as negative by local shepherds concerned with the security of their livestock (although interpretations are not necessarily one-to-one dependent on user's profiles). These groups of stakeholders thus hold different preferences (subjective social indicator) for the bear population size (objective biophysical indicator). Divergent interpretations of the same indicator can result in conflicting usages and practices when not properly addressed. Once an outcome is produced, it still needs to be given a meaning, which is what socio-cultural values are about. Through explicitly linking the preferences for a management option (here, on bear population sizes) with how the ecosystem matters for different actors, it is possible to address which notions of importance and meaning play a role in the choice for management scenarios and thus take them into account during management decision making. The process of giving meaning can differ for different stakeholders and according to the contextual setting of the evaluation (Gomez-Baggethun et al., 2014). It can also relate to different services. By confusing performance with importance or by only assessing one of both, these observations would be lost in the blender of "values". This could be quite problematic given that they withhold important information for making decisions and communicating about the eventual bear population policy and what roles and functions of the area (the national park in this case) are being prioritized.

To summarize, performance-oriented ES value indicators and SC values are strongly intertwined with one another, with the first being dependent on the latter. This does not preclude that they also are of a distinct nature and should thus not be confused in ES assessments. Therefore, indicators within an ES assessment framework should (1) be assessed at these two levels (performance and importance) to (2) enable a proper accounting of the connection between performance indicators and meanings. As a result, while performance-oriented value indicators and SC values both provide relevant information, the most interesting aspect of addressing both aspects of performance and importance, is that it allows for a better understanding of how these distinct indications regarding the 'value' of a given ES interact.

Another important notion about the way SC values are assessed in this study concerns the idea of relative importance. By this we refer to how much a(n) (bundle of) ES matters relative to other ES, as well as to how this differs according to different stakeholders, which reflects the idea of certain meanings being prioritized over others (Masterson et al., 2019). This relativity was enforced through the methodology (see Section 3.4), and while it does not imply that some values necessarily have to be more important than others, it does make it possible, on an aggregated level, to identify priority values for the overall public as well as for specific stakeholder groups (though the latter has not been dealt with in this study). Once SC values have been assessed, the aim is to explore the links between these contextual values and the connections with performance-oriented ES value indicators. Within this study, the latter are subjective social indicators and assessed through concrete preferences (see Section 3.3).

The following diagram (Fig. 1) mainly draws on the ES cascade- 


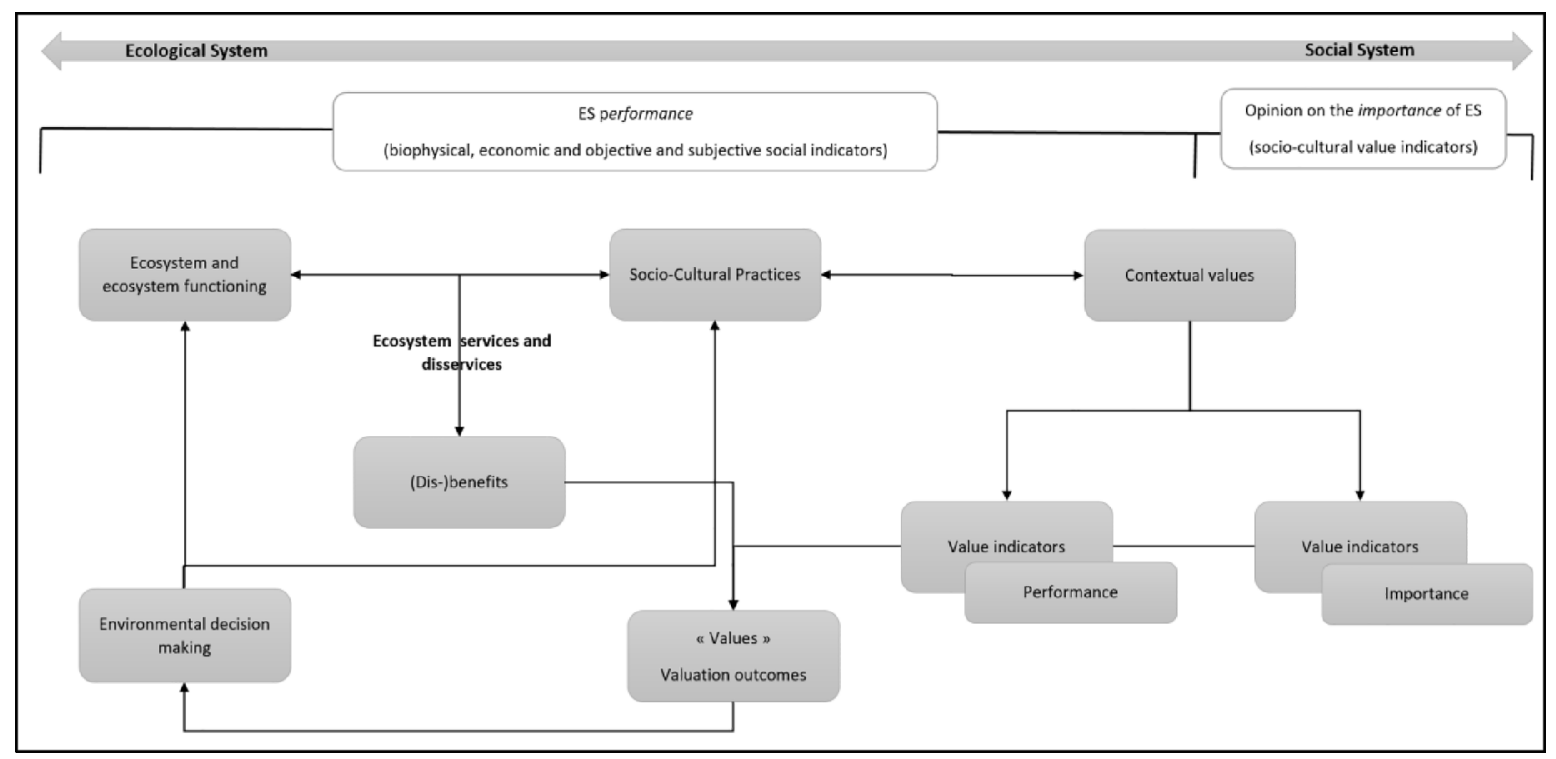

Fig. 1. A schematic overview of the concepts used within this study.

model by Haines-Young and Potschin (2010) and on the framework for conceptualizing cultural ES by Fish et al. (2016). It provides a schematic overview of the concepts and their linkages as outlined above. ES and their resulting (dis)benefits are interpreted as outcomes of the interactions between ecosystems and human agency (Ernstson, 2013), the latter encompassing both 'socio-cultural practices' and 'contextual values' as pictured in Fig. 1. ES valuation outcomes can both concern performance-oriented indicators (i.e. assessed in this study through preferences as social value indicators) as well as indicators reflecting an opinion of importance (i.e. are assessed through the use of socio-cultural value indicators).

\subsection{The added value of a socio-cultural importance-performance approach}

Rather than a fixed set, the set of socio-cultural values that can be taken into account should be flexible and depends on both the specific situational context and on the research settings (Barnaud et al., 2018; Reyers et al., 2013). Its meaning-making can vary for different stakeholders since it assesses the criticality of variable social interpretations of ecosystems and their services (see the issue "Critical for whom?" in de Groot et al., 2010). By differentiating between performance and importance, a SC value approach represents an elegant way to cope with the current conflation between value meanings. By a SC value approach, we refer to (1) the double assessment of subjective social indicators that assess the performance of ES and of SC values that assess the opinions on the importance of ES; (2) an assessment of the correlation between these two forms of indications; and (3) an interpretation of those correlations. By contextualizing subjective performance-oriented indicators through highlighting their interactions with SC values, the SC value approach could foster consensus-building and improve the legitimacy of compromises. Through a case study we will demonstrate its potential to bring both transparency and legitimacy to decision-making processes, e. g., by identifying common ground between stakeholders as well as by recalling the (inter)dependencies between stakeholders and services.

\section{Materials and methods}

\subsection{Concretizing SC values: The attractiveness of natural landscapes}

To demonstrate the relevance of distinguishing performance from importance in order to address the meaning making behind subjective social value indicators within ES evaluations, we focus on the ES, "attractiveness of natural landscapes".

The "attractiveness of natural landscapes" is traditionally evaluated within the category of cultural ecosystem services (Haines-Young and Potschin, 2012; MEA, 2005). The purpose of most of these evaluations is to estimate the recreational and touristic potential, monetary value or the potential number of visitors of a certain area. This is done either indirectly by testing certain indicators such as trail density, the number of red list species, the presence of water bodies, etc. (e.g. Nahuelhual et al., 2013; Schägner et al., 2018), or directly through expressed preferences or count data (e.g. Chhetri and Arrowsmith, 2008). These evaluations describe the situation of the service by means of evaluation indicators and rarely assess the relative importance of this service with respect to other services. As a consequence, they also ignore the interdependencies between for example ecotourism or recreation and other service-dependent benefits, values or stakeholders. For instance, when focusing on the ES, "attractiveness of landscapes", a specific interest (e.g. tourism) is linked to a specific profile (e.g. a tourist), which might obscure a multitude of reasons why the visitor cares about the landscape; these reasons may form part of the motivation for tourism but are ignored during the assessment. By assessing both subjective social value indicators and SC values, this could allow for the inclusion of other aspects into the ecosystem services assessment, even if this is not the main objective of the specific study.

The ES, "attractiveness of natural landscapes", is extremely well suited to demonstrate the relevance of distinguishing and combining performance-oriented subjective value indicators and socio-cultural values. This is because of the above-mentioned usual framing as a single cultural ES, as well as because of the multiplicity of stakeholders related to this ES, whether they be (potential) users or managers. This multiplicity can lead to diverging preferences on (specific elements of) management options and consequently give rise to potential conflicts. For a given case-study we will evaluate landscape preferences (as indicators of performance), as well as opinions on the (relative) importance of ES provided by the same landscape in order to demonstrate the added-value of this approach.

\subsection{Case study area}

The area of our case study, the Ardennes forests, is a geographical unit of $11,200 \mathrm{~km}^{2}$ that stretches over parts of Belgium, Luxembourg and France (see Fig. 2). Our focus concerns the Belgian (Walloon) part. 


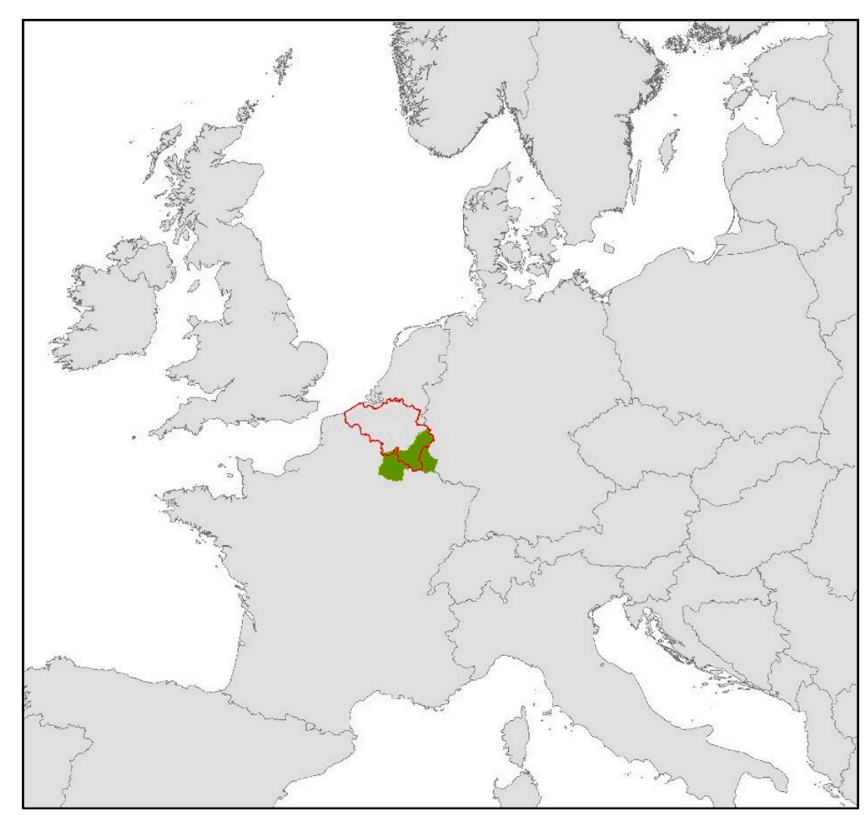

Fig. 2. The geographical localization of the case study area. The trans-border Ardennes forests are indicated in green, Belgian borders are highlighted in red.

These forests include large open areas such as prairies, peatlands, clearings, etc. Its specific location, with 6 million people living within a buffer radius of $100 \mathrm{~km}$, gives the Ardennes a peri-urban character, implying a high existing and potential demand for tourism and recreational activities (Colson et al., 2010). While traditional focuses on wood production and hunting activities remain important, eco-tourism is increasingly being seen as an economic alternative with the potential to stimulate the local economy and diversify activities in a way that is consistent with the protection and promotion of biodiversity (Filot, 2005; Laurent and Lecomte, 2007). Moreover, recent findings have emphasized the demand for a more explicit integration of social and ecological forest dimensions (Rametsteiner et al., 2009), with an observed shift in societal values away from predominantly instrumental and towards multifunctional values (Kendal and Raymond, 2019; Uggla, 2017).

Conflicts related to forest management have recently increased at the European and worldwide scale (Mormont, 2006). In the case of the Ardennes forests, indicators of potential conflicts include: citizen demonstrations against possible sales of public forests (mpOC, n.d.), a petition against current hunting practices ("Stop aux dérives de la chasse Pour une réforme radicale de la chasse, stoppons les dérives de la chasse," n.d.), the return of the wolf to the Ardennes (Denayer and Bréda, 2020), management of the african swine fever (Baily, 2018) and management of the bark beetle (Ips typographus) outbreak in spruce plantations (Forêt, 2021, in press). These elements concerning Ardennes forest management render this study area very suitable for assessing the interest of evaluating interactions between subjective social value indicators and SC values.

\subsection{Survey}

An online survey was outsourced to the private company Kantar ("Global Data Insights," n.d.) in order to obtain a sample of 1516 respondents (after elimination of speedsters), of which 286 were French, 686 Belgian, 278 Dutch and 266 German. Country proportions were defined by the authors of this study, based on the main visiting nations of the Ardennes forests ${ }^{1}$. The representativeness of each country sample was verified for the following socio-economic variables: gender, age, income level and education. Even though the fact that outsourcing the survey to a private company might induce some bias regarding the profiles of the respondents in their panel, the company was responsible for guaranteeing a country-wise representativeness for the gender and age variables. Three versions of the survey were used: Dutch, French and German. Respondents were contacted by mail. The survey was conducted in April 2019 and took an average of $17 \mathrm{~min}$. to complete. It consisted of five main parts: (A) introduction; (B) respondent profiling and scoring of SC values; (C) frequency and nature of visits to natural areas in the Ardennes; (D) preference questions and discrete choice experiments (DCE) on structural forest characteristics and on touristic infrastructure; and (E) socio-economic variables. Parts B and D are of major importance within this paper since they deal with performanceoriented indicators (preferences) and SC values; they thus serve to illustrate the conceptual reflection outlined above.

The orientation towards the wider public as a sampling group is relevant since it is a concerned actor in various ways: in terms of its tax contribution to the management of public forests (Byg et al., 2017), as residents of the area, as potential visitors (Turkelboom et al., 2018), and in terms of gaging public opinion about the importance and meaning of natural areas in contrast to local interest groups. Following this reasoning, we evaluate whether or not responses differ between residents and non-residents of the Ardennes region in all of the analyses. When relevant, we divide non-residents into effective visitors (who visited the Ardennes forests at least once during the last 12 months), occasional visitors (who have already visited the Ardennes forests, but not during the last 12 months) and potential visitors (who have not yet visited the Ardennes forests).

While this information was available via the survey, respondents were intentionally not further classified into user categories for this research (e.g., naturalist, hunter, forest owner, tourist, etc.). The aim of this study was to focus on common or opposing values within the wider public in general, without relying on a categorization of actors, which could mask within group heterogeneity (Turkelboom et al., 2018). Moreover, since a single person can belong to several categories at once (Barnaud et al., 2018). This implies a superposition of categories, which is not the case when using SC values. Also, the majority of the categories was poorly represented due to our focus on the general public. Although it might have been interesting to look at differences based on sociodemographic variables as well, this was outside the scope of this research (a part from assessing the sample's representativeness).

A preliminary version of the survey, using the same methodology, was implemented in November 2018. It served as a test for improving questions in terms of formulation, content and representation, which ensures the high quality of the final results of April 2019, used for this paper.

\subsection{Subjective social value indicators}

To reflect the performance of the ecosystem service, "attractiveness of natural landscapes", we evaluated the preferences of the wider public for structural forest attributes as subjective social value indicators. Four attributes were retained after reviewing the literature (Giergiczny et al., 2015; Hoyos, 2010; Nordén et al., 2017) and checking for their relevance for forest management options and for the Ardennes territory. These attributes are: species composition (coniferous vs. broadleaf), even vs. uneven aged forests, presence or absence of deadwood, and openness of the landscape (whether they be closed forests or forests that include open areas due to clear-cuts, or that include semi-natural open

\footnotetext{
${ }^{1}$ Due to confidentiality issues, it was not possible to include respondents from Luxembourg, who are also frequent Ardennes visitors.
} 
areas such as peatlands or pastures). Respondents were asked to indicate their preference for each attribute, represented using simplified black and white images, as can be seen in Fig. 3. The choice for these basic illustrations instead of images, for example, was to avoid the unintentional influencing of respondents by light, colors, season, weather, etc., that would have been presented on the images. The attribute 'openness' was then split into two variables: one dummy variable describing the continuity of forests (closed (0) or open (1)), and

Variation in tree height

\begin{tabular}{|ll|}
\hline & Presence of dead wood \\
\hline Absence of dead wood & Presence of dead wood \\
\hline
\end{tabular}

Continuous forests Forest Cover

Fig. 3. The attributes used for the preference questions on structural forest attributes. 
one variable describing the type of openness of the forests (clear-cuts (0) or semi- natural open areas (1)). We checked for differences in preferences (represented as binary variables) between residents and nonresidents using non-parametric chi-square tests.

We then regrouped preferences for forest attributes according to three management schemes: 'natural forests', 'artificial forests' (more intensively managed and more production-oriented forests) and 'other' forests. In total, there are 24 possible combinations of attributes or scenarios. 'Species composition' was not included to define the management models. Even though Ardennes 'artificial forests' are mainly dominated by coniferous species, this is not an exclusive given. We defined 'natural forests' by: the presence of deadwood, semi-natural open areas within the forests and uneven aged forests. This combination regroups two scenarios out of 24. 'Artificial forests' were defined through the combination of: the absence of deadwood, even aged forests and continuous forests or open areas due to clear-cuts, representing four scenarios out of 24 . All other combinations were grouped into the 'other' group representing the remaining 18 scenarios. We used R Studio statistical software (version 1.2.1335) for all of the analyses.

\subsection{Socio-cultural values (SC values)}

The relative importance of the SC values attributed to the Ardennes forests by the wider public was evaluated on the basis of scoring. Table 1 below specifies the typology of SC values used for this survey. This typology is based on a literature review (Bagstad et al., 2016; Brown and Reed, 2000; De Vreese et al., 2016; Raymond et al., 2009; Sherrouse et al., 2017; 2014;; Smith and Ram, 2017; van Riper et al., 2012). It has thereafter been adapted to the local context based on the recurrent mention of certain values during several informal encounters with a

Table 1

The socio-cultural (SC) values presented to the respondents.

\begin{tabular}{|c|c|}
\hline \multicolumn{2}{|c|}{ Socio-cultural values and their explanation } \\
\hline Socio-cultural value & Explicative phrase showed to the respondent \\
\hline & The Ardennes forests are important to me because \\
\hline Aesthetic value & ... I can enjoy the views, sounds, smells, etc. \\
\hline Biodiversity value & $\begin{array}{l}\text {... they provide a habitat for wild animals, plants and } \\
\text { microorganisms. }\end{array}$ \\
\hline Direct economic value & $\begin{array}{l}\text {... they provide economic products such as timber, } \\
\text { mushrooms, game, etc. }\end{array}$ \\
\hline Indirect economic value & $\begin{array}{l}\ldots \text { they create jobs because of their touristic } \\
\text { attractiveness, of which I can make use as a user or } \\
\text { operator from the touristic sector. }\end{array}$ \\
\hline $\begin{array}{l}\text { Extensive recreational } \\
\text { value }\end{array}$ & $\begin{array}{l}\text {... they provide a space for my outdoor activities such as } \\
\text { hiking, biking, observation of fauna and flora, etc. }\end{array}$ \\
\hline $\begin{array}{l}\text { Intensive recreational } \\
\text { value }\end{array}$ & $\begin{array}{l}\ldots \text { they provide a space for my outdoor activities such as } \\
\text { quad, } 4 \times 4 \text {, MTB circuits, mass events, etc. }\end{array}$ \\
\hline Bequest value & $\begin{array}{l}\text {... they allow future generations to know and experience } \\
\text { these forests. }\end{array}$ \\
\hline Patrimonial value & $\begin{array}{l}\text {... they are part of the cultural patrimony in the same way } \\
\text { as villages, abbeys, castles, etc., and they are part of the } \\
\text { history of the region. }\end{array}$ \\
\hline Relational value & $\begin{array}{l}\text {... they provide a place to create or reinforce social } \\
\text { relationships (outings with family or friends, working } \\
\text { environment, etc.) }\end{array}$ \\
\hline Mistrust value & $\begin{array}{l}\text {... one could feel ill at ease in those forests because they } \\
\text { create fears (of getting lost, they are dark and gloomy, } \\
\text { etc.) }\end{array}$ \\
\hline Life Support value & $\begin{array}{l}\ldots \text { in the battle against climate change and the } \\
\text { maintenance of a healthy living environment through the } \\
\text { renewal of soil, air, water, etc. }\end{array}$ \\
\hline $\begin{array}{l}\text { Inspirational/ } \\
\text { Therapeutic value }\end{array}$ & $\begin{array}{l}\ldots \text { they are inspiring places and make one feel better, } \\
\text { physically as well as mentally. }\end{array}$ \\
\hline Disservice value & $\begin{array}{l}\ldots \text { they can also have a negative impact on daily life (less } \\
\text { room for urbanization or agriculture, pests or damage by } \\
\text { wildlife, etc.) }\end{array}$ \\
\hline
\end{tabular}

$\overline{\text { Respondents could only see the explicative phrase (second column) and had } 100}$ points to divide up between these SC values. variety of local stakeholders (forest guards, hunters, tourism operators, private forest owners, institutions active on natural resource management, etc.). These encounters took place during autumn 2017 in the context of the preparatory phase of the overall funding project. Participatory observation to several local events on the topic of the (management of the) Ardenne forests (conferences, round-tables, excursions, expositions, etc.) also contributed to the selection. Retained SC values were selected when considered relevant for both locals and tourists, and some specific subdivisions were made to account for the ecotourismoriented setting of the overall project. The SC values mentioned in Table 1 all refer to the importance of ES or a set of ES. Since services can also have important negative repercussions (Blanco et al., 2019), two SC values for disservices have been included. A preliminary version (sample of 775 respondents) of the survey had an 'other value' option in the event that an important value was overlooked. However, since this option was rarely used, this was left out of the final version. Also, for this final version, the order of the SC values presented to respondents was randomized in order to control for this influence.

Respondents were asked to score SC values by distributing a total of 100 'votes' over 13 SC values, consequently enforcing an indication of their relative importance. It was not obligatory to include all the mentioned SC values in the scoring; an automatic counter was used for this question to avoid miscalculations.

The overall scoring of SC values and the variance of the sample was visualized by using a violin plot, for which values underwent a log +1 transformation, commonly used to minimize the effect of outliers (Garson, 2012). ANOVA tests (R package 'ggplot' v. 2.21) and Tukey's post hoc tests were used to check if residents and visitors (effective, occasional and potential) differed in their scoring. Where assumptions of normality or equal variances were not met, non-parametrical Kruskal Wallis and Dune's tests (R package 'FSA' v. 0.8.25) were used. Dune's tests made use of the p-adjustment method, as defined by Benjamini and Hochberg (BH) (Benjamini and Hochberg, 1995).

\subsection{Detailing the used social value indicators and socio-cultural values}

Table 2 outlines how SC values have been interpreted for this paper by borrowing from the notions of value lenses and dimensions described by Kenter et al. (2019).

While the specific categories of the dimensions 'intention' and 'justification' are inherent to the concept of SC values, the specific categories regarding the other dimensions result from the methodological framing of the study. Since SC values should cover a range of ES services, the intentions of SC values are both self- and other-regarding, depending on which specific SC value for ES is being addressed. SC values should concern all three ways of justification to allow for a broad range of meanings. For this case study, respondents in were individually asked to indicate how important a SC value for the study area is for them personally. The dimensions of provider and scale thus both concerned the individual level. As far as the assessment method is concerned, the chosen elicitation process was non-deliberative and resorted to the use of stated values; each SC value was then aggregated from individual levels to represent the wider public's opinion.

The subjective social value indicators used for this study assess public preferences for visual forest characteristics and thus entail an instrumental justification. Respondents were individually asked to state their personal preferences, which were then aggregated.

\subsection{Linking social value indicators with socio-cultural values}

To examine the correlation between social value indicators and socio-cultural values, we assessed for correlations between the three predefined management models ('natural', 'other' and 'artificial' forests) and the SC values. One approach could have been to test the correlations between all SC values and each structural forest characteristic separately. Nevertheless, the choice was made to adopt a three-way 
Table 2

An overview of the addressed value dimensions and categories, borrowing from Kenter et al. (2019).

\begin{tabular}{|c|c|c|c|c|c|}
\hline Lenses & Dimensions & Key question & Categories & SC values (Case study) & $\begin{array}{l}\text { Social value indicators (Case } \\
\text { study) }\end{array}$ \\
\hline \multirow[t]{5}{*}{ Value lens } & Concept & What does one mean by 'values'? & $\begin{array}{l}\text { - Transcendental values } \\
\text { - Contextual values } \\
\text { - Value indicators }\end{array}$ & Contextual values & Value indicators \\
\hline & Provider & At what scale are values being expressed? & $\begin{array}{l}\text { - Individual scale } \\
\text { - (Pre)-aggregated social } \\
\text { scales }\end{array}$ & Individual & Individual \\
\hline & Scale & $\begin{array}{l}\text { What is the scale of the values being } \\
\text { expressed? }\end{array}$ & $\begin{array}{l}\text { - Individual scale } \\
\text { - Social scales }\end{array}$ & Individual & Individual \\
\hline & Intention & $\begin{array}{l}\text { Who is being regarded with the expression of } \\
\text { values? }\end{array}$ & $\begin{array}{l}\text { - Self-regarding } \\
\text { - Other-regarding }\end{array}$ & Both & Self-regarding \\
\hline & Justification & How are values justified? & $\begin{array}{l}\text { - Instrumental } \\
\text { - Intrinsic } \\
\text { - Relational }\end{array}$ & All three ways & Instrumental \\
\hline \multirow[t]{2}{*}{$\begin{array}{l}\text { Procedural } \\
\text { lens }\end{array}$} & Elicitation & What process is used to elicit values? & $\begin{array}{l}\text { - Stated } \\
\text { - Deliberated } \\
\text { - Revealed }\end{array}$ & Stated & Stated \\
\hline & Aggregation & How are values aggregated? & $\begin{array}{l}\text { - Aggregated from } \\
\text { individuals } \\
\text { - Pre-aggregated }\end{array}$ & $\begin{array}{l}\text { Aggregated from } \\
\text { individuals }\end{array}$ & Aggregated from individuals \\
\hline
\end{tabular}

management approach since, in the opinion of the authors, it better reflects the adopted management practices in the Ardennes forests and thus facilitates the interpretation of results. We made use of one-way ANOVA (analysis of variance) and t-Tukey's tests of means on the logged SC values. Equal variances were assessed using Bartlett's test. Where assumptions of normality or equal variances were not met, nonparametrical alternatives were used, i.e., a Kruskal Wallis and Dune's test. The BH p-adjustment method was used for Dune's tests. The purpose of the above analyses was to evaluate whether SC values can offer an interpretation the outcomes of the preference assessment.

\section{Results}

The survey sample was representative (verified per country) in terms of gender. Concerning age, there were slightly less people representing the youngest age class. The sample was overrepresented for the highest income class as well as for the highest educational level, which is a common issue for Internet-based surveys (Menegaki et al., 2016). These demographical characteristics only served for verifying the representativeness of the sample respective to the general population They will thus not be further dealt with within this paper.

\subsection{Preferences}

Table 3 summarizes expressed preferences in percentages. On average, we observe a strong preference for characteristics of 'natural forests', such as the presence of deadwood, uneven aged forest layers and semi-natural open areas within the forests, over characteristics of plantation or highly managed forests, further referred to as 'artificial forests'. Continuous forests are slightly preferred over forests with clearcut areas, but semi-natural open areas within forests are clearly

Table 3

Overall preferences (rounded off) for forest attributes.

\begin{tabular}{lll}
\hline Structural forest attributes & & \\
\hline Attribute & Level & Percentage (\%) \\
\hline Species & Coniferous & 35.75 \\
& Broadleaf & 64.25 \\
Deadwood & Absent & 20.32 \\
& Present & 79.68 \\
Evenness & Even & 12.34 \\
& Uneven & 87.66 \\
Forest cover & Continuous & 16.82 \\
& Clear-cut & 13.32 \\
& Natural & 69.85 \\
\hline
\end{tabular}

identified as being the most attractive. On average, broadleaf species are preferred over coniferous species. Residents, when compared to nonresidents, had a less strong preference for the following characteristics: uneven aged forests $(\mathrm{p}<0.001)$, presence of deadwood $(\mathrm{p}<0.001)$, discontinuous forests $(\mathrm{p}<0.05)$ and semi-natural open areas $(\mathrm{p}<$ 0.001).

\subsection{Socio-cultural values}

Fig. 4 represents the average scoring of the SC values selected in this study, ordered by importance, from highest scored to least scored.

All SC values were selected by the whole set of the respondents to explain why the Ardennes forests are important to them, although some SC values appear more important than others. The overall top three contain SC values for the aesthetic services of the forests, for biodiversity conservation and for the renewal of air, water and soil (life support). Negative services, mistrust and disservices appear at the end of the ranking, but their importance is stronger for residents than for nonresidents (both $\mathrm{p}<0.001$ ). Moreover, residents have higher SC values for intensive recreational services $(\mathrm{p}<0.001)$ and effective visitors have higher SC values for therapeutic services compared to occasional or potential visitors (both $\mathrm{p}<0.01$ ).

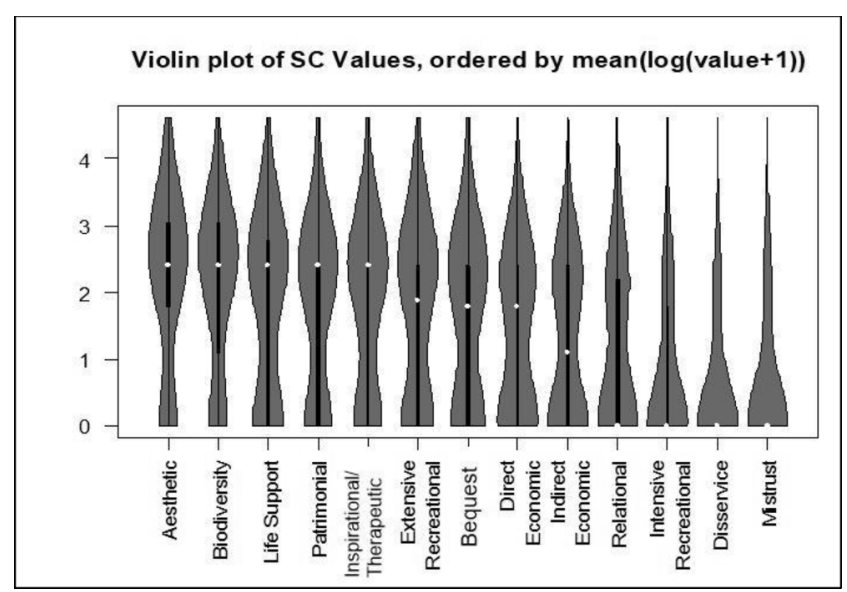

Fig. 4. Violin plot representation of the 13 scored SC values, ordered by mean $(\log ($ value +1$)$. 


\subsection{Linking social value indicators with socio-cultural values}

We evaluated whether or not SC values significantly differ between the three predefined management models by using one-way ANOVA tests and the post-hoc Tukey test of means. A total of 874 people chose the combination that was identified as a 'natural' forest, 79 people opted for the combination classified as 'artificial' forest, and the remaining 563 people chose combinations that were referred to as 'other'. The results are summarized in Table 4. Respondents who prefer 'natural forests' scored 'aesthetic' and 'biodiversity' values higher; while respondents who prefer 'artificial forests' scored 'mistrust', 'intensive recreational', 'indirect' and 'direct economy', 'relational' and 'disservice' values higher. SC values for 'bequest', 'patrimonial', 'therapeutic/ inspirational' and extensive recreational services do not significantly differ between management models. Note that the SC value for 'Life support' services is not scored significantly different between 'natural' and 'artificial' forests.

\section{Discussion}

The wider public concerned with the Ardennes forests, including residents and non-residents, has the overall tendency to prefer characteristics of 'natural forests' over 'artificial forests' (plantations or highly managed forests). Clearly, the presence of deadwood, natural open areas and uneven aged forests are preferred over the absence of deadwood, continuous forests or the presence of clear-cut areas and even aged forests. Moreover, broadleaf species are preferred almost twice as much over (non-indigenous) coniferous species. These findings are consistent with previous studies of forest perceptions (Colson, 2007; Edwards et al., 2012; Horne et al., 2005). Overall preferences coincide with features of forest management that favor biodiversity (du Bus de Warnaffe and Lebrun, 2004; Felipe-Lucia et al., 2018; Verheyen et al., 2006).

While certain services are objectively important for society, irrespective of where they may rank in valuations based on subjective preferences (Gómez-Baggethun \& de Groot 2010), preferences here seem to match a management system that would also benefit from a variety of ES (Lewis et al., 2019; Maebe et al., 2018; Radu, 2006).

As mentioned before, respondents were not classified into user categories (e.g., hunters, foresters, etc.). For this study, we instead focused on the opinions of the wider public (including residents and nonresidents). Extra attention should be paid to residents who resulted more moderate in their 'natural forests' choice and could thus show reluctance when management changes are envisioned. This could be due to the socio-economic dependency of the region on timber and hunting revenues (Carnol et al., 2014).

More recently, researchers have called for mainstreaming integrated ecosystem service assessments. This means that ES assessments should take biophysical, social and economic value indicators into account and that the relationships between these indicators, as well as between stakeholders and services, should be dealt with (Boeraeve et al., 2015; Jacobs et al., 2016; Kenter et al., 2016; Martín-López et al., 2014). While we follow Kronenberg and Andersson (2019) in that a fully integrated valuation (including all relevant values/dimensions/stakeholders) is not always possible, nor desirable, SC values can reinforce this integration by underlining the various ways in which an ecosystem matters. Hence, other important services (i.e. than the ones that are the scope of the research) are made explicit and their relative importance can be assessed for different types of stakeholders. Bearing this in mind, this paper considered the interactions between preferences (as subjective value indicators of the performance of the ES landscape attractiveness) and socio-cultural values (as an expression of the relative importance of ES), in order to properly interpret the outcomes of an ES assessment. The following main insights are discussed in more detail in the next paragraphs: (1) SC values can help to remind dependencies between services; (2) addressing SC values can facilitate the interpretation and integration of objective and subjective value indicators; and (3) addressing SC values can be useful for processes of negotiation, legitimization and communication of natural resource practices.

First, even though the survey was framed around the ES landscape attractiveness, results reveal that respondents take a variety of ecosystem services into account when scoring SC values. This observation implies paying attention to dependencies and trade-offs between services, which are often ignored (Martín-López et al., 2014). For instance, aesthetic services, to which people attributed the most importance, depend heavily on the way economic services are carried out through forest management practices, meaning that the first is subordinate to the latter. Addressing SC values can help to remind us of these dependencies during ES assessments since (1) both aesthetic and economic interests are valued; (2) aesthetic interests were deemed more important than economic interests; and (3) preferences for forest characteristics correlated with aesthetic importance differ from those correlated with economic importance.

Second, certain preferences are correlated with specific SC values. SC values offer a way to interpret the expressed preferences (Gomez-Baggethun et al., 2014) and thus to give meaning to objective indicators assessing an ES. For example, SC values for 'aesthetic', and 'biodiversity' services are correlated with preferences for characteristics of 'natural forests'. This correlation could imply a consistency in the concrete

Table 4

ANOVA or Kruskal Wallis and t-Tukey's tests of means or Dune's test, comparing the scoring of SC values between the preference groups for three predefined management models ('natural', 'other' and 'artificial').

\begin{tabular}{|c|c|c|c|c|c|}
\hline \multicolumn{6}{|c|}{ Results of the scoring of SC values according to forest preferences } \\
\hline \multirow[t]{2}{*}{ SC VALUE } & \multirow{2}{*}{$\begin{array}{l}\text { ANOVA/Kruskal } \\
\text { Wallis } \operatorname{Pr}(>\mathrm{F})\end{array}$} & \multirow{2}{*}{$\begin{array}{l}\text { Bartlett's test for } \\
\text { equal variances }\end{array}$} & \multicolumn{3}{|c|}{ Tukey's test of means/Dune's test } \\
\hline & & & Natural & Other & Artificial \\
\hline Aesthetic & $\mathrm{p}<0.001$ & yes & $\mathrm{A}+$ & $\mathrm{A}+$ & B \\
\hline Biodiversity & $\mathrm{p}<0.001$ & yes & $\mathrm{A}+$ & B & B \\
\hline Bequest & $\mathrm{p}=0.693$ & yes & A & A & A \\
\hline Life Support & $\mathrm{p}<0.001$ & yes & $\mathrm{A}+$ & $\mathrm{B}$ & $\mathrm{AB}$ \\
\hline Direct economic & $\mathrm{p}<0.05$ & yes & A & $\mathrm{AB}$ & $\mathrm{B}+$ \\
\hline Inspirational/Therapeutic & $\mathrm{p}=0.715$ & yes & A & A & A \\
\hline Mistrust & $\mathrm{p}<0.001$ & no & A & $\mathrm{B}+$ & $\mathrm{C}+$ \\
\hline Patrimonial & $\mathrm{p}=0.336$ & yes & A & A & A \\
\hline Intensive recreational & $\mathrm{p}<0.001$ & no & A & $\mathrm{B}+$ & $\mathrm{C}+$ \\
\hline Extensive recreational & $\mathrm{p}=0.293$ & yes & A & A & A \\
\hline Indirect economic & $\mathrm{p}<0.01$ & yes & A & A & $\mathrm{B}+$ \\
\hline Relational & $\mathrm{p}<0.001$ & yes & A & $\mathrm{B}+$ & $\mathrm{B}+$ \\
\hline Disservice & $\mathrm{p}<0.001$ & no & A & $\mathrm{B}+$ & $\mathrm{C}+$ \\
\hline
\end{tabular}

$+=$ significantly higher values compared to the other groups.

A,B,C = groups that are significantly different from each other for a certain SC value. 
visualization of theoretic concepts by the wider public. This does not amount to saying that people necessarily include these theoretic concepts in a fully conscious manner. Indeed, the quantitative approach pursued in this survey does not suffice for comprehending this sort of finer information. Ideally, quantitative and qualitative methods should thus be combined in ecosystem services assessments (Stålhammar and Pedersen, 2017). While this research constitutes an exploratory application of the SC value approach as described in this paper, the intention is to deepen the meaning-making aspect by integrating qualitative methods in future research. The inclusion of qualitative information would generate further insights, notably on whether people associate SC values and performance-oriented indicators when taking a survey such as the one presented in this paper. In addition, a qualitative approach would more directly allow for assessing how people make meaning, either individually or collectively, of ES performances in relation to a specific place (Klain et al., 2017; Tadaki et al., 2017).

In the same vein, 'artificial forests' that are generally less appreciated, are preferred by people who attributed a higher score to the SC values for 'disservices', 'mistrust', 'direct economic, 'intensive recreational', and 'relational' services. On the one hand, this might indicate that these 'artificial forests' are associated with certain negative perceptions through their structural characteristics. On the other hand, they are perceived as being important for their economic contribution, the ease with which they can be used for intensive recreational activities or for supervising the territory, and their role in creating or maintaining social structures, the latter probably being related to the timber industry and/or hunting activities (Carnol et al., 2014). The association between 'artificial forests' and the SC value for direct economic contributions seems to indicate that people perceive intensively managed forests as having a higher productivity and cost efficiency than 'natural forests', while this is not necessarily always true (Dieler et al., 2017; Liang et al., 2016).

Along a similar line of reasoning, the SC value for 'life support' services is not scored differently between 'natural' and 'artificial' management models. This could indicate that the wider public perceives these services as being equally well performed by highly managed or by more 'natural' forests. However, research reveals that 'natural' forests are more effective in terms of life support services than forest plantations (Lewis et al., 2019). These findings underpin the importance of combining subjective social value indicators of forest preferences with biophysical value indicators of, for example, forest productivity or a forest's capacity for carbon removal to check for perceived associations. In this way, visualizing SC values can facilitate the interpretation and integration of both objective and subjective indicators during ES assessments. Again, to further interpret this correlation, it would be advisable to combine it with qualitative research methodologies.

Third, an understanding of which values are favored through the choice of a specific management scheme can lead to the questioning of the consistency and legitimacy of dominant discourses (Mormont, 2006). The SC value "biodiversity", for example, is cited as the second most important for the Ardennes forests by the wider public, while 'direct economic' revenues are ranked eighth out of thirteen. However, this relative importance does not seem to be satisfactorily accounted for, neither in the observed situation on the field nor in the general policies or local management plans.

The Walloon forestry code (Code Forestier, 2008) incorporated the general concept of 'multi-functionality' of the forest, generally conceived and interpreted as an integrated ES scheme with the simultaneous achievement of social, environmental and economic goals (Scohy, 2017). However, this has not yet proved its efficiency to significantly trigger general forest management practices towards satisfactory results in terms of biodiversity services (Maebe et al., 2019; Wibail and Farcy, 2018). Dead wood, for example, as a key indicator of forest biodiversity (Radu, 2006), is highly preferred by the wider public in our study. Despite this, the average volume of dead wood for the Walloon forests is estimated at $8.2 \mathrm{~m}^{3}$ /ha (Alderweireld et al., 2015), largely below the 336 to $555 \mathrm{~m}^{3}$ /ha found in natural forests (Bobiec, 2002) ${ }^{2}$. Moreover, societal expectations for more 'natural forests' contrast with the actual landscape of Walloon forests, where intensively planted and managed (mostly non-indigenous species) forests occupy more than the half of the forested area (Alderweireld et al., 2015).

Furthermore, numerous incentive policies (e.g., public subsidies for high-density coniferous plantations) and/or actual practices (e.g., conversion of ancient broadleaf forest into planted coniferous forests on the public domain) appear to be contradictory to the declared increased attention paid to biodiversity and life support services (Wibail and Farcy, 2018). As expressed elsewhere, this might well be a form of a 'lock-in' process (Maréchal, 2010; Vanloqueren and Baret, 2008). Among the elements that contribute to locking-in 'artificial forest' practices are the false associations on which policies sometimes rest (such as the above example of perceived exclusivity between economic productivity and intensive forest management—see Drouet (2018)).

In order to achieve a forest policy that is accepted and supported by the public and that thus diminishes the risk of conflicts, a thorough understanding of the diverse values associated with those forests is essential (Anderson et al., 2018). Kenter et al. (2016) point out that even though a democratization of values could enhance a more sustainable and equitable decision-making process in terms of natural resource management, democratic deficits often persist. The observations in this study hint at a certain mismatch between societal values, preferences and actual forest management. This mismatch has also been observed in other studies (Buijs et al., 2011; Deuffic et al., 2018; Edwards et al., 2016; Uggla, 2017), where forest managers seem to have focused mainly on (productive or ecological) performance, while residents focus on a variety of forest meanings (e.g. aesthetics, sense of place, ...).

This observation calls for rethinking the way forest policies and practices are decided on and put into practice. As an illustration, we briefly reflect on the example of the bark beetle outbreak mentioned in the case study description. Although they are often assumed to be less productive, natural forests have been proven to be more resilient to pest outbreaks, compared to spruce plantations (Faccoli and Bernardinelli, 2014). Our results show that turning to a more nature-based management would thus account for the overall preferences and SC values that predominantly appear in the wider public's opinion. This observation could serve as an argument to defend a potential change in actual forest management policies.

This reflection shows that SC values could reveal flaws in certain discourses, as well as promoting a renewed management of forests that would correspond to changing societal needs and values. Addressing SC values can lead to new perspectives concerning established discourses and practices. It must be noted, however, that the selection of addressed SC values plays an important role for the interpretation of the results. SC values that were not included in this survey (e.g. educational values, sense of place) may represent important issues that were overlooked and therefore limit the insights that can be retained from this study.

\section{Conclusions}

This study indicates that we should distinguish the importance of an ecosystem service from its performance. The results indeed show that socio-cultural values offer a useful complement to interpret outcomes of subjective valuations of performance. SC values offer a simple and practical way to include affective valuation in ES assessments and to assist their integrated evaluation. This is because (1) SC values can help to remind us of the dependencies between services; (2) addressing SC values can facilitate the interpretation and integration of objective and subjective value indicators; and (3) visualizing SC values can help stimulate debate concerning forest management, legitimize (or contest)

\footnotetext{
${ }^{2}$ The 'critical threshold value' for volumes of deadwood in 'natural' low-land oak-beech forests is estimated at $30-50 \mathrm{~m}^{3}$ /ha (Müller and Bütler, 2010).
} 
future decision-making processes, improve communication between stakeholders, and offer possible insights into consensus-building based on common values.

As outlined in Section 3.3, we purposely addressed the wider public instead of looking for extreme viewpoints correlated with existing conflicting discourses. This approach allows us to contextualize subjective performance-oriented indicators, to look for common ground between stakeholders, and to question the legitimacy of actual management and dominant discourses. However, in order to further analyze the policy potential of this approach, it is advisable to repeat the methodology while addressing specific stakeholder groups and with a more qualitative, place-based approach to understand how people make meaning. This would make it possible to determine whether or not the discourses proponed by the representatives of these groups are coherent with their manifested SC values, and if their preferences and relative importance significantly differs from the wider public.

Finally, even though the aim is to include multiple sets of values in ecosystem services assessments, this study is a contribution to research on Western studies. However, as mentioned earlier, the list of SC values depends on the contextual settings and can be modified accordingly. Therefore, the use of the SC value concept to interpret subjective performance-oriented indicators in an ecosystem services assessment could provide an added-value in a non-Western context as well.

To conclude, relevant forest management undoubtedly requires the assessment of ecosystem services. Our results also show that sociocultural values should not be neglected since touching upon importance and meaning-making (and the ensuing possibility to adequately interpret subjective performance-oriented indicators) is crucial for a sound ecosystem service assessment and for adopting socially accepted management strategies.

\section{Declaration of Competing Interest}

The authors declare that they have no known competing financial interests or personal relationships that could have appeared to influence the work reported in this paper.

\section{Acknowledgements}

Our thanks go to Dr. Nicolas Dendoncker for his helpful comments on the manuscript. We also thank Dr. Jens Abildtrup for evaluating the representativeness of the survey sample.

\section{Funding}

This work was supported by the Interreg Europe program under the AGRETA (Ardenne Grande Région, Eco-Tourisme et Attractivité) project (2.336.460,77€, 2017-2020).

\section{References}

Alderweireld, M., Burnay, F., Pitchugin, M., Lecomte, H., Inventaire Forestier Wallon-Résultats 1994-2012, SPW, 2015.

Anderson, N., Ford, R.M., Bennett, L.T., Nitschke, C., Williams, K.J.H., 2018. Core values underpin the attributes of forests that matter to people. For. Int. J. For. Res. 91, 629-640. https://doi.org/10.1093/forestry/cpy022.

Aretano, R., Petrosillo, I., Zaccarelli, N., Semeraro, T., Zurlini, G., 2013. People perception of landscape change effects on ecosystem services in small Mediterranean islands: a combination of subjective and objective assessments. Landsc. Urban Plan. 112, 63-73.

Arias-Arévalo, P., Martín-López, B., Gómez-Baggethun, E., 2017. Exploring intrinsic, instrumental, and relational values for sustainable management of social-ecological systems. Ecol. Soc. 22 https://doi.org/10.2307/26799016.

Bagstad, K.J., Reed, J.M., Semmens, D.J., Sherrouse, B.C., Troy, A., 2016. Linking biophysical models and public preferences for ecosystem service assessments: a case study for the Southern Rocky Mountains. Reg. Environ. Change 16, 2005-2018. https://doi.org/10.1007/s10113-015-0756-7.

Baily, O., Chasse. Les seigneurs des Ardennes [WWW Document], 2018, ghttps://medor. coop/fr/articles/enquete-chasse/ (Accessed 2.15.19).
Barnaud, C., Antona, M., Marzin, J., 2011. Vers une mise en débat des incertitudes associées à la notion de service écosystémique. VertigO. https://doi.org/10.4000/ vertigo.10905.

Barnaud, C., Corbera, E., Muradian, R., Salliou, N., Sirami, C., Vialatte, A., Choisis, J.-P., Dendoncker, N., Mathevet, R., Moreau, C., Reyes-García, V., Boada, M., Deconchat, M., Cibien, C., Garnier, S., Maneja, R., Antona, M., 2018. Ecosystem services, social interdependencies, and collective action: a conceptual framework. Ecol. Soc. 23 https://doi.org/10.5751/ES-09848-230115.

Benjamini, Y., Hochberg, Y., 1995. Controlling the false discovery rate: a practical and powerful approach to multiple testing. J. R. Stat. Soc. Ser. B Methodol. 57, 289-300.

Berbés-Blázquez, M., González, J.A., Pascual, U., 2016. Towards an ecosystem services approach that addresses social power relations. Current Opinion in Environmental Sustainability, Sustainability science 19, 134-143. https://doi.org/10.1016/j. cosust.2016.02.003.

Blanco, J., Dendoncker, N., Barnaud, C., Sirami, C., 2019. Ecosystem disservices matter: towards their systematic integration within ecosystem service research and policy. Ecosyst. Serv. 36, 100913 https://doi.org/10.1016/j.ecoser.2019.100913.

Bobiec, A., 2002. Living stands and dead wood in the Białowieża forest: suggestions for restoration management. For. Ecol. Manag. 165, 125-140. https://doi.org/10.1016/ S0378-1127(01)00655-7.

Boeraeve, F., Dendoncker, N., Jacobs, S., Gomez-Baggethun, E., Dufrêne, M., 2015. How (not) to perform ecosystem service valuations: pricing gorillas in the mist. Biodivers. Conserv. 24, 187-197.

Breslow, S.J., Allen, M., Holstein, D., Sojka, B., Barnea, R., Basurto, X., Carothers, C., Charnley, S., Coulthard, S., Dolšak, N., Donatuto, J., García-Quijano, C., Hicks, C.C., Levine, A., Mascia, M.B., Norman, K., Poe, M., Satterfield, T., Martin, K.S., Levin, P. S., 2017. Evaluating indicators of human well-being for ecosystem-based management. Ecosyst. Health Sustain. 3, 1-18. https://doi.org/10.1080/ 20964129.2017.1411767.

Brondízio, E.S., Gatzweiler, F.W., Zografos, C., Kumar, M., Jianchu, X., McNeely, J. Kadekodi, G.K., Martinez-Alier, J., 2010. Socio-cultural context of ecosystem and biodiversity valuation. The Economics of Ecosystems and Biodiversity (TEEB) $149-174$.

Brown, G., Reed, P., 2000. validation of a forest values typology for use in national forest planning. For. Sci. 46, 240-247. https://doi.org/10.1093/forestscience/46.2.240.

Bryce, R., Irvine, K.N., Church, A., Fish, R., Ranger, S., Kenter, J.O., 2016. Subjective well-being indicators for large-scale assessment of cultural ecosystem services. Ecosyst. Serv. 21, 258-269.

Buijs, A.E., Arts, B.J.M., Elands, B.H.M., Lengkeek, J., 2011. Beyond environmental frames: the social representation and cultural resonance of nature in conflicts over a Dutch woodland. Geoforum, Themed Issue Subaltern Geopolitics 42, 329-341. https://doi.org/10.1016/j.geoforum.2010.12.008.

Byg, A., Martin-Ortega, J., Glenk, K., Novo, P., 2017. Conservation in the face of ambivalent public perceptions - the case of peatlands as 'the good, the bad and the ugly'. Biol. Conserv. 206, 181-189.

Cáceres, D.M., Tapella, E., Quétier, F., Díaz, S., 2015. The social value of biodiversity and ecosystem services from the perspectives of different social actors. Ecol. Soc. 20 https://doi.org/10.5751/ES-07297-200162.

Carnol, M., Baeten, L., Branquart, E., Grégoire, J.-C., Heughebaert, A., Muys, B., Ponette, Q., Verheyen, K., 2014. Ecosystem services of mixed species forest stands and monocultures: comparing practitioners' and scientists' perceptions with formal scientific knowledge. For. Int. J. For. Res. 87, 639-653. https://doi.org/10.1093/ forestry/cpu024.

Chan, K.M., Satterfield, T., Goldstein, J., 2012. Rethinking ecosystem services to better address and navigate cultural values. Ecol. Econ. 74, 8-18.

Chhetri, P., Arrowsmith, C., 2008. GIS-based modelling of recreational potential of nature-based tourist destinations. Tour. Geogr. 10, 233-257.

Christie, M., Martín-López, B., Church, A., Siwicka, E., Szymonczyk, P., Mena Sauterel, J., 2019. Understanding the diversity of values of "Nature's contributions to people": insights from the IPBES Assessment of Europe and Central Asia. Sustain. Sci. 14, 1267-1282. https://doi.org/10.1007/s11625-019-00716-6.

CICES, Common International Classification of Ecosystem Services (CICES) V5.1, 2018.

Code Forestier, Décret relatif au Code forestier, 2008.

Colson, V., 2007. La fréquentation des massifs forestiers wallons: le public, ses activités et sa perception de la forêt. For. Wallonne 20-35.

Colson, V., Garcia, S., Rondeux, J., Lejeune, P., 2010. Map and determinants of woodlands visiting in Wallonia. Urban For. Urban Green. 9, 83-91.

Costanza, R., de Groot, R., Braat, L., Kubiszewski, I., Fioramonti, L., Sutton, P., Farber, S., Grasso, M., 2017. Twenty years of ecosystem services: How far have we come and how far do we still need to go? Ecosyst. Serv. 28, 1-16. https://doi.org/10.1016/j. ecoser.2017.09.008.

Daily, G.C., Polasky, S., Goldstein, J., Kareiva, P.M., Mooney, H.A., Pejchar, L., Ricketts, T.H., Salzman, J., Shallenberger, R., 2009. Ecosystem services in decision making: time to deliver. Front. Ecol. Environ. 7, 21-28. https://doi.org/10.1890/ 080025.

Davies, K.K., Fisher, K.T., Dickson, M.E., Thrush, S.F., Le Heron, R., 2015. Improving ecosystem service frameworks to address wicked problems. E\&S 20, art37. https://doi.org/10.5751/ES-07581-200237.

de Groot, R.S., Alkemade, R., Braat, L., Hein, L., Willemen, L., 2010. Challenges in integrating the concept of ecosystem services and values in landscape planning, management and decision making. Ecol. Complex. Ecosyst. Serv. Bridging Ecol. Econ. Social Sci. 7, 260-272. https://doi.org/10.1016/j.ecocom.2009.10.006.

De Vreese, R., Leys, M., Dendoncker, N., Van Herzele, A., Fontaine, C.M., 2016. Images of nature as a boundary object in social and integrated ecosystem services assessments. Reflections from a Belgian case study. Ecosyst. Serv. 22, 269-279. https://doi.org/ 10.1016/j.ecoser.2016.06.008. 
Denayer, D., Bréda, C., 2020. Si le Loup y était... Quelles compétences humaines et animales sont instaurées dans l'anticipation d'une coexistence située ? (Région wallonne, Belgique). Anthropologica 62, 105-118. https://doi.org/10.3138/ anth.2018-0098.r2.

Dendoncker, N., Boeraeve, F., Crouzat, E., Dufrêne, M., König, A., Barnaud, C., 2018. How can integrated valuation of ecosystem services help understanding and steering agroecological transitions? Ecol. Soc. 23 https://doi.org/10.5751/ES-09843230112.

Deuffic, P., Sotirov, M., Arts, B., 2018. "Your policy, my rationale". How individual and structural drivers influence European forest owners' decisions. Land Use Policy 79, 1024-1038. https://doi.org/10.1016/j.landusepol.2016.09.021.

Díaz, S., Demissew, S., Carabias, J., Joly, C., Lonsdale, M., Ash, N., Larigauderie, A., Adhikari, J.R., Arico, S., Báldi, A., 2015. The IPBES conceptual framework-connecting nature and people. Curr. Opin. Environ. Sustain. 14, 1-16.

Díaz, S.M., Pataki, G., Roth, E., Watson, R.T., Al-Hafedh, Y.S., Ahn, S., Amankwah, E., Asah, S.T., Balvanera, P., Breslow, S.J., Bullock, C.H., Cáceres, D.M., Chobotová, V., Daly-Hasen, H., Basak Dessane, E., Figueroa, E., Golden, C., Gómez-Baggethun, E., Islar, M., Kelemen, E., Kumar, R., Ma, K., Maris, V., Masozera, M., May, P.H., Mead, A., Mohamed, A., Moran, D., O'Farrell, P., Pacheco, D., Pandit, R., Pengue, W. A., Pichs, R., Popa, F., Povazan, R., Quaas, M.F., Rakotobe, T., Saarikoski, H., Strassburg, B., Subramanian, S.M., Beltvan den, M., Verma, M., Wang, X., Wickson, F., Wittmer, H., Yagi, N., Barbier, E.B., Burton, M., Houdet, J., Keune, H., Liu, S., Maynard, S., Portela, R., Spierenburg, M.J.. https://www.researchgate.net/ publication/271529734.

Dieler, J., Uhl, E., Biber, P., Müller, J., Rötzer, T., Pretzsch, H., 2017. Effect of forest stand management on species composition, structural diversity, and productivity in the temperate zone of Europe. Eur. J. For. Res. 136, 739-766. https://doi.org/ 10.1007/s10342-017-1056-1.

F.X. Drouet, Le temps des forêts, 2018.

du Bus de Warnaffe, G., Lebrun, P., 2004. Effects of forest management on carabid beetles in Belgium: implications for biodiversity conservation. Biol. Conserv. 118, 219-234. https://doi.org/10.1016/j.biocon.2003.08.015.

Edwards, D., Jay, M., Jensen, F., Lucas, B., Marzano, M., Montagné, C., Peace, A., Weiss, G., 2012. Public preferences across europe for different forest stand types as sites for recreation. Ecol. Soc. 17 https://doi.org/10.5751/ES-04520-170127.

Edwards, D.M., Collins, T.M., Goto, R., 2016. An arts-led dialogue to elicit shared, plural and cultural values of ecosystems. Ecosyst. Serv. Shared Plural Cult. Val. 21, 319-328. https://doi.org/10.1016/j.ecoser.2016.09.018.

Ernstson, H., 2013. The social production of ecosystem services: a framework for studying environmental justice and ecological complexity in urbanized landscapes. Landsc. Urban PlanSpecial Issue Urban Ecosyst. Serv. 109, 7-17. https://doi.org/ 10.1016/j.landurbplan.2012.10.005.

Faccoli, M., Bernardinelli, I., 2014. Composition and elevation of spruce forests affect susceptibility to bark beetle attacks: implications for forest management. Forests 5 , 88-102. https://doi.org/10.3390/f5010088.

Felipe-Lucia, M.R., Soliveres, S., Penone, C., Manning, P., van der Plas, F., Boch, S., Prati, D., Ammer, C., Schall, P., Gossner, M.M., Bauhus, J., Buscot, F., Blaser, S., Blüthgen, N., de Frutos, A., Ehbrecht, M., Frank, K., Goldmann, K., Hänsel, F., Jung, K., Kahl, T., Nauss, T., Oelmann, Y., Pena, R., Polle, A., Renner, S., Schloter, M., Schöning, I., Schrumpf, M., Schulze, E.-D., Solly, E., Sorkau, E., Stempfhuber, B., Tschapka, M., Weisser, W.W., Wubet, T., Fischer, M., Allan, E., 2018. Multiple forest attributes underpin the supply of multiple ecosystem services. Nat. Commun. 9, 1-11. https://doi.org/10.1038/s41467-018-07082-4.

Filot, O., 2005. L'usage de la forêt wallonne. Courr. Hebd. CRISP 1892, 5-51.

Fish, R., Church, A., Winter, M., 2016. Conceptualising cultural ecosystem services: a novel framework for research and critical engagement. Ecosyst. Serv. 21, 208-217.

Forêt, Naturalité, 2021. La crise du scolyte de l'épicéa, enfin une opportunité pour une forêt plus naturelle en Wallonie? Forêt \& Naturalité.

Garson, G.D., 2012. Testing statistical assumptions. NC Stat. Assoc. Publ., Asheboro.

Giergiczny, M., Czajkowski, M., Żylicz, T., Angelstam, P., 2015. Choice experiment assessment of public preferences for forest structural attributes. Ecol. Econ. 119, $8-23$.

Global Data Insights [WWW Document], n.d. . Light. Res. URL http://www. lightspeedresearch.com/ (accessed 8.19.19).

E. Gomez-Baggethun, B. Martin-Lopez, D.N. Barton, L. Braat, E. Kelemen, M. GarciaLlorente, H. Saarikoski, J. van den Bergh, State-of-the-art report on integrated valuation of ecosystem services (EU FP7 OpenNESS report No. Deliverable D.4.1/ WP4) European Commission, 2014.

Gould, R.K., Pai, M., Muraca, B., Chan, K.M.A., 2019. He 'ike 'ana ia i ka pono (it is a recognizing of the right thing): how one indigenous worldview informs relational values and social values. Sustain. Sci. 14, 1213-1232. https://doi.org/10.1007/ s11625-019-00721-9.

Haines-Young, R., Potschin, M., 2012. Common international classification of ecosystem services (CICES, Version 4.1). Eur. Environ. Agency 33, 107.

Haines-Young, R., Potschin, M., 2010. The links between biodiversity, ecosystem services and human well-being. Ecosyst. Ecol. New Synth. 110-139.

Harrington, R., Anton, C., Dawson, T.P., de Bello, F., Feld, C.K., Haslett, J.R., Kluvankova-Oravska, T., Kontogianni, A., Lavorel, S., Luck, G.W., 2010. Ecosystem services and biodiversity conservation: concepts and a glossary. Biodivers. Conserv. 19, 2773-2790.

Hauck, J., Görg, C., Varjopuro, R., Ratamäki, O., Maes, J., Wittmer, H., Jax, K., 2013. "Maps have an air of authority": potential benefits and challenges of ecosystem service maps at different levels of decision making. Ecosyst. Serv. 4, 25-32. https:// doi.org/10.1016/j.ecoser.2012.11.003.

Horne, P., Boxall, P.C., Adamowicz, W.L., 2005. Multiple-use management of forest recreation sites: a spatially explicit choice experiment. For. Ecol. Manag. Decision
Support Multi Purpose Forest. 207, 189-199. https://doi.org/10.1016/j. foreco.2004.10.026.

Hoyos, D., 2010. The state of the art of environmental valuation with discrete choice experiments. Ecol. Econ. 69, 1595-1603. https://doi.org/10.1016/j. ecolecon.2010.04.011.

K.N. Irvine, L. O'Brien, N. Ravenscroft, N. Cooper, M. Everard, I. Fazey, M.S. Reed, J.O. Kenter, Ecosystem services and the idea of shared values, Serv. Ecosyst., (2016), doi: 10.1016/j.ecoser.2016.07.001.

Ishihara, H., 2018. Relational values from a cultural valuation perspective: how can sociology contribute to the evaluation of ecosystem services? Curr. Opin. Environ. Sustain., Sustain. Challeng. Rel. Values 35, 61-68. https://doi.org/10.1016/j. cosust.2018.10.016.

Jacobs, S., Dendoncker, N., Martín-López, B., Barton, D.N., Gomez-Baggethun, E., Boeraeve, F., McGrath, F.L., Vierikko, K., Geneletti, D., Sevecke, K.J., 2016. A new valuation school: integrating diverse values of nature in resource and land use decisions. Ecosyst. Serv. 22, 213-220.

Jax, K., Barton, D.N., Chan, K.M.A., de Groot, R., Doyle, U., Eser, U., Görg, C., GómezBaggethun, E., Griewald, Y., Haber, W., Haines-Young, R., Heink, U., Jahn, T., Joosten, H., Kerschbaumer, L., Korn, H., Luck, G.W., Matzdorf, B., Muraca, B., Neßhöver, C., Norton, B., Ott, K., Potschin, M., Rauschmayer, F., von Haaren, C., Wichmann, S., 2013. Ecosystem services and ethics. Ecol. Econ. 93, 260-268. https://doi.org/10.1016/j.ecolecon.2013.06.008.

Kendal, D., Raymond, C.M., 2019. Understanding pathways to shifting people's values over time in the context of social-ecological systems. Sustain. Sci. 14, 1333-1342. https://doi.org/10.1007/s11625-018-0648-0.

Kenter, J.O., 2019. Demystifying Shared and Social Values. Valuing Nature Program VNP20.

Kenter, J.O., Bryce, R., Christie, M., Cooper, N., Hockley, N., Irvine, K.N., Fazey, I., O'Brien, L., Orchard-Webb, J., Ravenscroft, N., 2016. Shared values and deliberative valuation: future directions. Ecosyst. Serv. 21, 358-371.

Kenter, J.O., O’Brien, L., Hockley, N., Ravenscroft, N., Fazey, I., Irvine, K.N., Reed, M.S., Christie, M., Brady, E., Bryce, R., 2015. What are shared and social values of ecosystems? Ecol. Econ. 111, 86-99.

Kenter, J.O., Raymond, C.M., van Riper, C.J., Azzopardi, E., Brear, M.R., Calcagni, F., Christie, I., Christie, M., Fordham, A., Gould, R.K., Ives, C.D., Hejnowicz, A.P., Gunton, R., Horcea-Milcu, A.-I., Kendal, D., Kronenberg, J., Massenberg, J.R., O'Connor, S., Ravenscroft, N., Rawluk, A., Raymond, I.J., Rodríguez-Morales, J., Thankappan, S., 2019. Loving the mess: navigating diversity and conflict in social values for sustainability. Sustain. Sci. 14, 1439-1461. https://doi.org/10.1007/ s11625-019-00726-4.

Klain, S.C., Olmsted, P., Chan, K.M.A., Satterfield, T., 2017. Relational values resonate broadly and differently than intrinsic or instrumental values, or the New Ecological Paradigm. PLOS ONE 12, e0183962. https://doi.org/10.1371/journal. pone.0183962.

Kollmuss, A., Agyeman, J., 2002. Mind the Gap: Why do people act environmentally and what are the barriers to pro-environmental behavior? Environ. Educ. Res. 8, 239-260. https://doi.org/10.1080/13504620220145401.

Kronenberg, J., Andersson, E., 2019. Integrating social values with other value dimensions: parallel use vs. combination vs. full integration. Sustain. Sci. 14, 1283-1295. https://doi.org/10.1007/s11625-019-00688-7.

Laurent, C., Lecomte, H., 2007. Les services environnementaux et sociaux rendus par la forêt. Rapport Analytique Sur l'état de l'environnement Wallon 2006-2007. Région Wallonie.

Lewis, S.L., Wheeler, C.E., Mitchard, E.T., Koch, A., 2019. Restoring natural forests is the best way to remove atmospheric carbon. Nature Publishing Group.

J. Liang, T.W. Crowther, N. Picard, S. Wiser, M. Zhou, G. Alberti, E.-D. Schulze, A.D. McGuire, F. Bozzato, H. Pretzsch, S. de-Miguel, A. Paquette, B. Hérault, M. SchererLorenzen, C.B. Barrett, H.B. Glick, G.M. Hengeveld, G.-J. Nabuurs, S. Pfautsch, et al., Positive biodiversity-productivity relationship predominant in global forests. Science, 354 (2016) aaf8957, doi: https://doi.org/10.1126/science.aaf8957.

Maebe, L., Claessens, H., Dufrêne, M., 2019. The critical role of abiotic factors and human activities in the supply of ecosystem services in the ES matrix. One Ecosyst. 4, e34769 https://doi.org/10.3897/oneeco.4.e34769.

L. Maebe, H. Claessens, M. Dufrêne, Balancing forest ecosystem services by adapting their management to the forest type and the ecological context: a case study in Southern Belgium, 2018.

Maréchal, K., 2010. Not irrational but habitual: the importance of "behavioural lock-in" in energy consumption. Ecol. Econ. 69, 1104-1114.

Martín-López, B., Gómez-Baggethun, E., García-Llorente, M., Montes, C., 2014. Tradeoffs across value-domains in ecosystem services assessment. Ecol. Indic. 37, 220-228. https://doi.org/10.1016/j.ecolind.2013.03.003.

Masterson, V.A., Enqvist, J.P., Stedman, R.C., Tengö, M., 2019. Sense of place in social-ecological systems: from theory to empirics. Sustain. Sci. 14, 555-564. https://doi.org/10.1007/s11625-019-00695-8.

Maynard, S., James, D., Davidson, A., 2015. Determining the value of multiple ecosystem services in terms of community wellbeing: Who should be the valuing agent? Ecol. Econ 115, 22-28. https://doi.org/10.1016/j.ecolecon.2014.02.002.

MEA, Millennium Ecosystem Assessment [WWW Document], 2015, https://www. millenniumassessment.org/en/Synthesis.html (Accessed 7.6.18).

Menegaki, A.N., Olsen, S.B., Tsagarakis, K.P., 2016. Towards a common standard-a reporting checklist for web-based stated preference valuation surveys and a critique for mode surveys. J. fChoice Model. 18, 18-50. https://doi.org/10.1016/j. jocm.2016.04.005.

Mormont, M., 2006. Conflit et territorialisation. Geogr. Econ. Soc. 8, 299-318.

mpOC, n.d. Actualisation de l'action: "Non à la privatisation des forêts publiques de Wallonie!-Mouvement politique des objecteurs de croissance (mpOC) [WWW 
Document]. https://objecteursdecroissance.be/spip.php?article768 (accessed 6.29.19).

Müller, J., Bütler, R., 2010. A review of habitat thresholds for dead wood: a baseline for management recommendations in European forests. Eur. J. For. Res. 129, 981-992. https://doi.org/10.1007/s10342-010-0400-5.

Munda, G., 2004. Social multi-criteria evaluation: methodological foundations and operational consequences. Eur. J. Oper. Res. 158, 662-677.

Nahuelhual, L., Carmona, A., Lozada, P., Jaramillo, A., Aguayo, M., 2013. Mapping recreation and ecotourism as a cultural ecosystem service: an application at the local level in Southern Chile. Appl. Geogr. 40, 71-82. https://doi.org/10.1016/j. apgeog.2012.12.004.

Nordén, A., Coria, J., Jönsson, A.M., Lagergren, F., Lehsten, V., 2017. Divergence in stakeholders' preferences: evidence from a choice experiment on forest landscapes preferences in Sweden. Ecol. Econ. 132, 179-195.

O'Connor, S., Kenter, J.O., 2019. Making intrinsic values work; integrating intrinsic values of the more-than-human world through the Life Framework of Values. Sustain. Sci. 14, 1247-1265. https://doi.org/10.1007/s11625-019-00715-7.

Pascual, U., Balvanera, P., Díaz, S., Pataki, G., Roth, E., Stenseke, M., Watson, R.T., Başak Dessane, E., Islar, M., Kelemen, E., Maris, V., Quaas, M., Subramanian, S.M. Wittmer, H., Adlan, A., Ahn, S., Al-Hafedh, Y.S., Amankwah, E., Asah, S.T., Berry, P. Bilgin, A., Breslow, S.J., Bullock, C., Cáceres, D., Daly-Hassen, H., Figueroa, E., Golden, C.D., Gómez-Baggethun, E., González-Jiménez, D., Houdet, J., Keune, H., Kumar, R., Ma, K., May, P.H., Mead, A., O’Farrell, P., Pandit, R., Pengue, W., PichisMadruga, R., Popa, F., Preston, S., Pacheco-Balanza, D., Saarikoski, H., Strassburg, B. B., van den Belt, M., Verma, M., Wickson, F., Yagi, N., 2017. Valuing nature's contributions to people: the IPBES approach. Curr. Opin. Environ. Sustain. 26-27, 7-16. https://doi.org/10.1016/j.cosust.2016.12.006.

Peltola, T., Arpin, I., 2017. How We Come to Value Nature? - A Pragmatist Perspective. Ecol. Econ. 142, 12-20. https://doi.org/10.1016/j.ecolecon.2017.06.009.

Pröpper, M., Haupts, F., 2014. The culturality of ecosystem services. Emphasizing process and transformation. Ecol. Econ. 108, 28-35.

Radu, S., 2006. The ecological role of deadwood in natural forests. In: Gafta, D., Akeroyd, J. (Eds.), Nature conservation: concepts and practice, environmental science and engineering. Springer, Berlin Heidelberg, pp. 137-141. https://doi.org/ 10.1007/978-3-540-47229-2_16.

Rametsteiner, E., Eichler, L., Berg, J., Aggestam, F., Binda Zane, E., Plumet, C., Rademaekers, R., 2009. Shaping forest communication in the European Union: public perceptions of forests and forestry. Final Rep ECORYS Rotterdam.

Rawluk, A., Ford, R., Anderson, N., Williams, K., 2019. Exploring multiple dimensions of values and valuing: a conceptual framework for mapping and translating values for social-ecological research and practice. Sustain. Sci. 14, 1187-1200. https://doi.org/ 10.1007/s11625-018-0639-1.

Raymond, C.M., Bryan, B.A., MacDonald, D.H., Cast, A., Strathearn, S., Grandgirard, A., Kalivas, T., 2009. Mapping community values for natural capital and ecosystem services. Ecol. Econ. 68, 1301-1315. https://doi.org/10.1016/j. ecolecon.2008.12.006.

Reyers, B., Biggs, R., Cumming, G.S., Elmqvist, T., Hejnowicz, A.P., Polasky, S., 2013. Getting the measure of ecosystem services: a social-ecological approach. Front. Ecol. Environ. 11, 268-273. https://doi.org/10.1890/120144.

Robertson, M.M., 2006. The nature that capital can see: science, state, and market in the commodification of ecosystem services. Environ. Plan. Soc. Space 24, 367-387.

Schägner, J.P., Brander, L., Paracchini, M.L., Maes, J., Gollnow, F., Bertzky, B., 2018. Spatial dimensions of recreational ecosystem service values: a review of metaanalyses and a combination of meta-analytic value-transfer and GIS. Ecosyst. Serv. 31, 395-409.

Scholte, S.S., van Teeffelen, A.J., Verburg, P.H., 2015. Integrating socio-cultural perspectives into ecosystem service valuation: a review of concepts and methods. Ecol. Econ. 114, 67-78.
J.P. Scohy, Une forêt publique aux multiples fonctions, in: Le Grand Livre de La Forêt. Forêt wallonne, Marche-en-Famenne, 2017, p. 496

Sherrouse, B.C., Clement, J.M., Semmens, D.J., 2011. A GIS application for assessing, mapping, and quantifying the social values of ecosystem services. Appl. Geogr. 31, 748-760. https://doi.org/10.1016/j.apgeog.2010.08.002.

Sherrouse, B.C., Semmens, D.J., Ancona, Z.H., Brunner, N.M., 2017. Analyzing land-use change scenarios for trade-offs among cultural ecosystem services in the Southern Rocky Mountains. Ecosyst. Serv 26, 431-444. https://doi.org/10.1016/j. ecoser.2017.02.003.

Sherrouse, B.C., Semmens, D.J., Clement, J.M., 2014. An application of Social Values for Ecosystem Services (SolVES) to three national forests in Colorado and Wyoming. Ecol. Indic. 36, 68-79. https://doi.org/10.1016/j.ecolind.2013.07.008.

Small, N., Munday, M., Durance, I., 2017. The challenge of valuing ecosystem services that have no material benefits. Glob. Environ. Change 44, 57-67. https://doi.org/ 10.1016/j.gloenvcha.2017.03.005.

Smith, M., Ram, Y., 2017. Tourism, landscapes and cultural ecosystem services: a new research tool. Tourism Recreation Research 42, 113-119. https://doi.org/10.1080/ 02508281.2016.1253206.

Spangenberg, J.H., Settele, J., 2016. Value pluralism and economic valuation-defendable if well done. Ecosyst. Serv. 18, 100-109.

Stålhammar, S., Pedersen, E., 2017. Recreational cultural ecosystem services: How do people describe the value? Ecosyst. Serv. 26, 1-9. https://doi.org/10.1016/j. ecoser.2017.05.010.

Stålhammar, S., Thorén, H., 2019. Three perspectives on relational values of nature. Sustain. Sci. 14, 1201-1212. https://doi.org/10.1007/s11625-019-00718-4.

Stop aux dérives de la chasse-Pour une réforme radicale de la chasse, stoppons les dérives de la chasse [WWW Document], n.d. https://stopderiveschasse.be/, (accessed 6.29.19).

Tadaki, M., Sinner, J., Chan, K.M.A., 2017. Making sense of environmental values: a typology of concepts. Ecol. Soc. 22.

Turkelboom, F., Leone, M., Jacobs, S., Kelemen, E., García-Llorente, M., Baró, F., Termansen, M., Barton, D.N., Berry, P., Stange, E., Thoonen, M., Kalóczkai, Á., Vadineanu, A., Castro, A.J., Czúcz, B., Röckmann, C., Wurbs, D., Odee, D., Preda, E., Gómez-Baggethun, E., Rusch, G.M., Pastur, G.M., Palomo, I., Dick, J., Casaer, J., van Dijk, J., Priess, J.A., Langemeyer, J., Mustajoki, J., Kopperoinen, L., Baptist, M.J., Peri, P.L., Mukhopadhyay, R., Aszalós, R., Roy, S.B., Luque, S., Rusch, V., 2018. When we cannot have it all: ecosystem services trade-offs in the context of spatial planning. Ecosyst. Serv. 29, 566-578. https://doi.org/10.1016/j. ecoser.2017.10.011.

Uggla, Y., 2017. Negotiating responsible forestry: forest owners' understanding of responsibility for multiple forest values. Environ. Sociol. 1-12. https://doi.org/ 10.1080/23251042.2017.1414659.

Van Riper, C.J., Kyle, G.T., 2014. Capturing multiple values of ecosystem services shaped by environmental worldviews: a spatial analysis. J. Environ. Manage. 145, 374-384. https://doi.org/10.1016/j.jenvman.2014.06.014.

van Riper, C.J., Kyle, G.T., Sutton, S.G., Barnes, M., Sherrouse, B.C., 2012. Mapping outdoor recreationists' perceived social values for ecosystem services at Hinchinbrook Island National Park, Australia. Appl. Geogr. 35, 164-173. https:// doi.org/10.1016/j.apgeog.2012.06.008.

Vanloqueren, G., Baret, P.V., 2008. Why are ecological, low-input, multi-resistant wheat cultivars slow to develop commercially? A Belgian agricultural 'lock-in'case study. Ecol. Econ. 66, 436-446.

Verheyen, K., Lust, N., Carnol, M., Hens, L., Bouma, J.J., 2006. Feasability of forest conversion: ecological, social and economic aspects (FEFOCON) (Scientific support plan for a sustainable development policy (SPSD II)).

Wibail, L., Farcy, C., 2018. Etat et résilience des milieux forestiers. 